\title{
Zakaz pobierania opłat półkowych - uwagi na tle najnowszego orzecznictwa
}

\author{
The prohibition to levy slotting fee - remarks on the basis \\ of the most recent case-law
} mgr Aleksandra Dziegielewska

E-mail: awdziegielewska@gmail.com; nr ORCID: 0000-0002-2438-9466

\begin{abstract}
Streszczenie
Zawarte w artykule rozważania koncentrują się wokół problematyki opłat półkowych, jak potocznie nazywa się opisa- ne w art. 15 ust. 1 pkt 4 ustawy o zwalczaniu nieuczciwej konkurencji, inne niż marża opłaty pobierane za przyjęcie to- waru do sprzedaży. Celem rozważań jest pokazanie zmiany, która dokonała się w ostatnich latach w orzecznictwie są- dów powszechnych dotyczącym tego zagadnienia. Ewolucja $\mathrm{w}$ sposobie interpretacji przedmiotowego przepisu, uwzględniająca argumentację Trybunału Konstytucyjnego z wyroku dotyczącego zgodności z Konstytucją zakazu opłat półkowych, przyczyniła się do ustalenia granic stosowania przepisu. Wnikliwa ocena stanu faktycznego, każdorazowo przeprowadzana przez sądy powszechne, chroni przed arbitralnością w orzekaniu na niekorzyść sprzedawców, co do niedawna stanowiło problem. Sądy są bardzo ostrożne przy wyrokowaniu, że w rozpatrywanej sprawie miał miejsce czyn nieuczciwej konkurencji.
\end{abstract}

Słowa kluczowe: opłata półkowa, czyn nieuczciwej konkurencji, ustawa o zwalczaniu nieuczciwej konkurencji

\section{Summary}

The article touches upon a problem of slotting fee, which is a common term used to describe any charges different than profit margin retrieved for accepting the wares into sale, as foreseen in the article 15.1 .4 of Act on combatingUnfairCompetition. The purpose of this study was to show that the case-law concerning this matter has changed within the past few years. The evolution in the way the article in question is being interpreted, which remains in line the Constitutional Court's indications included in its judgment concerning the constitutionality of the aforementioned provision, has contributed to finding the limits to the application of the slotting fee prohibition. A detailed assessment of the legal and factual situation carried out by the courts in each case, protects sellers from arbitrary judgments, which used to be the problem in the past. The courts are being very cautious while stating that in the case at hand an act of unfair competition took place.

Key words: slotting fee, act of unfair competition, Act on combating Unfair Competition

JEL: K21

Str. $20-25$

\section{Bibliografia}

Ciapała, J. (2009). Konstytucyjna wolność działalności gospodarczej w Rzeczypospolitej Polskiej. Szczecin: Uniwersytet Szczeciński.

Nestoruk, I. B. (2015). Swoboda dostępu do rynku a swoboda kontraktowania w kontekście zakazu opłat półkowych — stan aktualny. Przegląd Prawa Handlowego, (3), 25-32.

Nowińska, E., du Vall, M. (2013). Ustawa o zwalczaniu nieuczciwej konkurencji. Komentarz. Warszawa: Lexis Nexis.

Podrecki, P. (2014). Opłaty półkowe. Monitor Prawniczy, (6), 21-27.

Sieradzka, M. (2010). Glosa do wyroku SN z 12.06.2008 r., III CSK 23/08, LEX/el.

Skoczny, T., Bernatt, M. (2013). Czyny nieuczciwej konkurencji W: J. Szwaja (red.). Ustawa o zwalczaniu nieuczciwej konkurencji. Komentarz, Warszawa: C.H. Beck.

Sroczyński, J. (2013). Rabat retroaktywny a tzw. opłata półkowa: potrzeba racjonalizacji. Internetowy Kwartalnik Antymonopolowy $i$ Regulacyjny, (2), 93-104.

Szanciło, T. (2016). Premie pieniężne i podobne opłaty jako przedmiot czynu nieuczciwej konkurencji — uwagi polemiczne. Przegląd 
Sądowy, (4), 7-31.

\section{Akty prawne}

Konstytucja Rzeczypospolitej Polskiej z 2.04.1997 r. (Dz. U. nr 78, poz. 483 ze zm.).

Ustawa z 23.04.1964 r. — Kodeks cywilny (Dz. U. z 2018 r. poz. 1025 ze zm.).

Ustawa z 16.04.1993 r. o zwalczaniu nieuczciwej konkurencji (Dz. U. z 2018 r. poz. 419 ze zm.).

Ustawa z 5.07.2002 r. o zmianie ustawy o zwalczaniu nieuczciwej konkurencji (Dz. U. nr 126, poz. 1071).

\section{Orzeczenia sądowe}

Wyrok TK z 16.10.2014 r., SK 20/12, LEX nr 1523340.

Postanowienie SN z 26.04.2018 r., I CSK 781/17, LEX nr 2483694.

Wyrok SN z 12.06.2008 r., III CSK 23/08, LEX nr 449921.

Wyrok SN z 20.02.2014 r., I CSK 236/13, LEX nr 1466623.

Wyrok SN z 6.06.2014 r., III CSK 228/13, LEX nr 1506548.

Wyrok SN z 23.10.2014 r., I CSK 597/13, LEX nr 1545133.

Wyrok SN z 16.01.2015 r., III CSK 244/14, LEX nr 1648184.

Wyrok SN z 28.01.2015 r., I CSK 748/13, LEX nr 1663391.

Wyrok SN z 17.04.2015 r., I CSK 136/14, LEX nr 1710335.

Wyrok SN z 29.04.2016 r., I CSK 319/15, LEX nr 2061177.

Wyrok SN z 15.06.2018 r., I CSK 494/17, LEX nr 2505417.

Wyrok SN z 15.02.2018 r., I CSK 339/17, LEX nr 2506707.

Wyrok SN z 28.03.2018 r., V CSK 217/17, LEX nr 2521615.

Wyrok SN z 25.05.2018 r., I CSK 455/17, LEX nr 2556105.

Wyrok SN z 13.06.2018 r., IV CSK 262/17, LEX nr 2509656.

Wyrok Sądu Apelacyjnego w Warszawie z 17.11.2014 r., I ACa 696/14, LEX nr 1659151.

Wyrok Sądu Apelacyjnego w Poznaniu z 16.12.2014 r., I ACa 937/14.

Wyrok Sądu Apelacyjnego w Warszawie z 24.03.2015 r., I ACa 949/14, LEX nr 1659153.

Uchwała NSA z 25.06.2012 r., I FPS 2/12, LEX nr 1166015. 